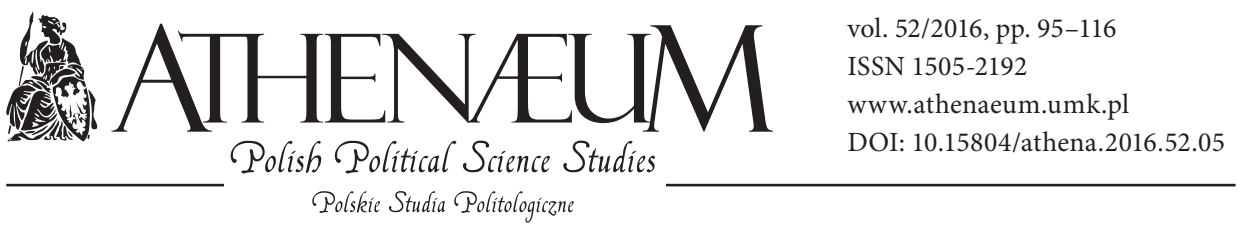

\title{
THE ROLE OF ECONOMIC FACTORS IN THE PROCESSES OF DEMOCRATIC CONSOLIDATION - THE CASE OF POST-REVOLUTIONARY TUNISIA*
}

\author{
ROLA CZYNNIKÓW EKONOMICZNYCH W PROCESACH \\ KONSOLIDACJI DEMOKRACII NA PRZYKŁADZIE \\ POREWOLUCYJNEJ TUNEZJI
}

Rachela Tonta**

In the last five years Tunisia has been presented mostly as a success story of political transition. It managed to adopt a new constitution and to conduct the parliamentary and presidential elections in 2014. Finally, civil society groups, which helped to end the political crisis in 2013, won the Nobel peace prize. If we look from the institutional perspective and the ability of political groups to compromise, indeed we can say that Tunisia is a success story. The picture is more bleak, however, if we try to assess the influence of economic factors on the development of Tunisian democracy, especially in light of recent terrorist attacks and social protests. The aim of the article
\end{abstract}

W ciągu ostatnich pięciu lat Tunezja była przedstawiana głównie jako przykład udanej transformacji politycznej. W 2014 roku została przyjęta nowa konstytucja, w oparciu o którą przeprowadzono wybory prezydenckie i parlamentarne. Co więcej, Kwartet na rzecz Dialogu Narodowego, który pomógł zakończyć kryzys polityczny w 2013 roku, został laureatem Pokojowej Nagrody Nobla. Patrząc z perspektywy reform instytucjonalnych oraz zdolności różnych grup do zawierania kompromisu, możemy niewątpliwie skonkludować, że transformacja polityczna w Tunezji okazała się sukcesem. Obraz ten staje się jednak mniej jednoznaczny, jeśli weźmie się pod uwagę wpływ

* This text was produced within a project "Islamism and Pluralism: The Islamist Movements in Egypt and Tunisia after the Arab Spring", financed by the National Science Centre (Poland) - Decision No. NCN-KR-0011/288/2/2012.

I would like to thank the Professor Krzysztof Trzciński for his valuable comments on an earlier draft of this article.

** Institute of Mediterranean and Oriental Cultures of the Polish Academy of Sciences. 
is to answer the questions, to what extent economic crisis can inhibit democratic consolidation in Tunisia and what Tunisia can learn from the Spanish experience of political transition.

Keywords: political transition, Tunisia, economic factors, democratization czynników ekonomicznych na rozwój demokracji, szczególnie w kontekście zamachów terrorystycznych oraz społecznych protestów, do których dochodziło w porewolucyjnej Tunezji. Celem artykułu jest udzielenie odpowiedzi na pytania, w jakim stopniu kryzysy ekonomiczne mogą zablokować procesy demokratycznej konsolidacji i czego Tunezja może się nauczyć z doświadczeń Hiszpanii okresu transformacji politycznej.

Słowa kluczowe: transformacja polityczna, Tunezja, czynniki ekonomiczne, demokratyzacja

The events of the Arab Spring have deemed it necessary to raise questions, not for the first time, about the direction of changes that have been initiated and if the building of a consolidated democracy is possible in this part of the world. So far, only Tunisia has managed to successfully complete the first stage of the transition processes, which includes the adoption of a new constitution and the conducting of parliamentary and presidential elections at the end of 2014. However, even if the country has made tremendous progress in terms of political reform, it is not yet determined whether Tunisia will become a consolidated democracy ${ }^{1}$. If we take into account the experiences of many other countries, which were seemingly stuck between authoritarian and democratic systems, momentary success proved ephemeral and does not mean that the whole process will be realized satisfactorily. This is also one of the points of criticism made against the theories of democratization and political transition, especially those developed in the $1980^{\mathrm{s}}$ and 1990s. In these theories this process was seen as linear with a need to pass through successive phases, and the final stage was seen as the consolida-

${ }^{1}$ For a number of researchers, such as O’Donnell, Schmitter, or Valenzuela, the consolidation of democracy is linked to the 'effective functioning of a democratic regime', which requires breaking with the old style politics, which means that undemocratic principles of action and cooperation or rules concerning the functioning of State institutions need to be changed. According to Linz and Stepan, democracy can be considered as consolidated only if it has become 'the only game in town'. The closest to the concept of a consolidated democracy is the category of 'full democracy', according to a democracy index developed by the Economist Intelligence Unit. According to the EIU in 2015, only 20 countries were among this group. Tunisia as a 'flawed democracy' is located in 57th position. 
tion of democracy, as if the outcome was pre-determined (Przeworski, 1991). As it turned out, however, the reality in a growing number of democratizing countries was completely different, because the process of democratization was accompanied by the development of different kinds of pathologies. As a result, it is difficult to name the political systems that developed in these counties as a democracy. Moreover, as Carothers noted (2002), even if we take into account only those examples of political transitions that can be considered 'successful' or 'promising', it is difficult to detect in them any regularity.

Regardless of the validity of this and other reservations, it can be assumed that even in a large number of countries having suffered transitional defeat, their aims, at least at a declarative level, were towards democracies limited not only to electoral processes, but above all guaranteeing broad civil rights, respect for rules of law, and the protection of human rights and economic freedom. When we talk about Tunisia in terms of a post-revolutionary society and elite classes, the developed democracies of the West were a more significant point of reference than the states whose regimes are closer to an authoritarian model. Therefore, bearing in mind the shortcomings of the theories of democratic transitions, we can still successfully take advantage of their elements, in order not only to understand the causes, nature and context of changes, but more importantly - to characterize in which direction they are moving. It is important to take these issues into account since in the majority of analyses of post-revolutionary changes in Tunisia, researchers have paid more attention to the institutional context of democratizing processes, the role of Islamism in the context of social and political pluralism, and have underestimated at the same time the role of (primarily) economic factors in the processes of consolidation of democracy. Hence, after the parliamentary and presidential elections of 2014, we could hear countless voices suggesting that Tunisian democratic transition was a complete success. In point of fact, in a number of scientific articles, reports and expert analysis, reference has been made to the economic problems that are regarded as one of the most important challenges facing Tunisia, but there was no comprehensive attempt to diagnose the problem in light of the theories of democratic transition and consolidation. What is more, most researchers treated economic issues as distinct from security problems, which makes the assessment of the influence of these problems on the development of the Tunisian democracy insofar as insufficient. Therefore, the article aims to fill this gap and to draw attention to the important link between economic factors and processes of democratic consolidation in this country. 


\section{ECONOMY AND THE CONSOLIDATION OF DEMOCRACY -}

\section{THEORETICAL ASPECTS}

Currently, researchers in their analysis dealing with the impact of economic factors on the processes of democratization/political transition, focus primarily on the quantitative study of the relationship between social inequalities, the wealth of the country counted per capita, the size of the middle class and the likelihood of introducing democratic changes (Acemoglu, Robinson, 2006; Boix, 2003; Houle, 2009).

Less attention has been paid to the role of economic factors in the processes of consolidation of democracy, which is mostly analysed in terms of the impact of inequality on the likelihood of a return to an authoritarian regime. According to Acemoglu and Robinson, this dependence should be understood as follows whereby, "greater inequality is likely to destabilize democracy because [...] the burden of democracy on the elites is increasing in the income gap between them and the citizens", and that, "higher levels of inequality still lead to democratization, but democracy is not consolidated because coups are attractive" (2006, p. 37). However, as Haggard and Kaufman have indicated, research in the area of 'distributive conflicts' is usually conducted by quantitative methods based on various economic indicators, and depending on what kind of indicators are used, we may get different results in our research. Specifically, the scientific tools which are used to analyse these inequalities have many limitations. Furthermore, the quality of available data may leave a lot to be desired, so the result may be a distortion of the actual socio-economic situation in any given country. As these researchers have demonstrated, only changing research methodology allowed them to challenge Acemoglu and Robinson, as well as the findings of Boix and Przeworski (Przeworski, Alvarez, Cheibub, Limongi, 2000) which indicate a significant relationship between distributional conflict and a return to an authoritarian system (Haggard, Kaufman, 2012). Therefore I agree with the approach of Hibou, who accordingly stated that statistical data "reflects the state-controlled knowledge" and should therefore be treated as belonging to a "mechanism of domination and control". Of course, this does not mean that we should completely reject them. However, they should be used to "understand the political and sociological significance of economic behaviour" (2011, p. 17).

To understand the impact of economic conditions on democratic consolidation, it is more useful to refer to the older literature on democratic transition. For example, in The Third Wave, written by Huntington (1991), of eight so called 
contextual problems which were selected as the most important challenges for countries undergoing democratic transitions, four problems are economic and refer to extreme poverty, large socio-economic inequality, inflation and substantial foreign debt. For Linz and Stepan, the survival of a young democracy depends on three vital issues, one of which is related to economics: the effectiveness of the state in addressing socio-economic problems. So the following question has arisen: does the state, which is struggling with economic problems, have a chance to successfully complete the process of democratic transition? Huntington argues that the 'weight' of such problems is not so important, but rather the way in which successive governments are trying to address these problems ${ }^{2}$. Stepan and Linz share similar views. According to them, the example of Spain, a country that after the death of Gen. Franco was struggling with rising unemployment and low economic growth, shows that the consolidation of democracy is still possible. The economic problems could not undermine democracy in Spain because for the majority of citizens, who still remembered very well the conduct of undemocratic governments, the rule of law and human rights protection were much more important factors. As a result, for Spanish society and the political elites, democracy was the only option to be taken into consideration. As Linz and Stepan stated: "[...] the political perception of desired alternatives has a greater impact on the survival of democratic regimes than economic and social problems per se" (2001, p. 140-150).

Huntington's insights, as well as Linz and Stephan's, were confirmed later on by a Swedish researcher of government 'quality', Bo Rothstein. He draws attention to the link between the consolidation of democracy and its quality. In his article on this subject, he took as examples the outbreak of the Spanish Civil War in 1936 and the wars in the former Yugoslavia in the 90s. According to him, in both cases the failure of democratic consolidation was the result of governmental incompetence that was unable to control corruption and in a broader aspect to guarantee the rule of law, both of which resulted in the declining legitimacy of Spanish and Yugoslavian regimes. Rothstein in his text also refers to the study of Dhalmberg and Holmberg, according to whom the effectiveness of governments in solving different kinds of problems is even more important for voters than whether their interests are reflected at the level of structures of power (Rothstein, 2014).

2 "It is the way in which political leaders respond to their inability to solve the problems confronting their country" (Huntington, 1991, p. 259). 
The challenges that Tunisia is currently facing do not seem to be particularly unique. From the perspective of macro-economic indicators, weak economic growth, rising inflation and high unemployment, especially among young people, can be compared to the situation in democratizing Spain, experiences of which can be considered as proof that economic problems do not have to directly translate into an inhibition of the consolidation processes. The official macro-economic data, however, gives us only a limited picture of the situation in Tunisia, and therefore does not give us the possibility to make a realistic assessment about the direction of changes in the future. I am going to demonstrate that the Spanish model of dealing with economic problems during democratic transition may prove unattainable for Tunisia, since economic problems could become a much larger obstacle for democratic consolidation than Huntington, Stepan and Linz had anticipated.

\section{BEN ALI'S ECONOMIC MIRACLE}

The story of the Tunisian 'economic miracle' is already well known. Over the years, Tunisia has been presented as the fastest growing country in Africa, tightening an economic partnership with the European Union, with a thriving middle class and a well-educated population. For international financial institutions Tunisia has become the model state in the first decade of the twenty-first century: with a growing economy, a tight monetary policy, inflation kept in check, a decreasing percentage of the population living below the poverty threshold and a consistent implementation of the provisions of a free trade agreement with the EU. The events of the Arab Spring, however, allowed for an effective deconstruction of the 'economic miracle' discourse created by the Ben Ali regime; a discourse which tried to hide, under a surface of statistical tables and graphs, the scale of poverty, social inequality, and social and economic pathologies. If we look from the perspective of democratization processes in Tunisia, the refutation of the 'economic miracle' myth has not only symbolic value, but it also allows us to characterize the economic legacy of the authoritarian regime. It is important because "the economic legacy of authoritarian rule determines the policy agenda of its democratic successors" (Haggard, Kaufman, 1997, p. 277).

When Zine El Abidine Ben Ali gained power in 1987, the Tunisian economy was in stagnation. At that time the Tunisian government had to deal with the issues of under-development in different sectors of the economy, low economic 
growth, unemployment and an increasing dependence on foreign loans with regards to internal development. In just one decade foreign debt increased sevenfold, reaching 4.9 billion dollars in 1985, and long-term debt alone comprised of $61 \%$ of GDP (Murphy, 1999). Even before the removal of president Habib Bourguiba from power, efforts were undertaken to liberalize the economy under the auspices of the International Monetary Fund and the World Bank, in return for which Tunisia had received further tranches of foreign loans. The new president, Ben Ali, in his economic policy did not intend to deviate from the policy of liberalization initiated by his predecessor and further plans for economic development in Tunisia were based on the assumption that only an intensification of liberalization policies could provide rapid economic development. So other reform plans, approved by international institutions, were primarily aimed at reducing the budget deficit, accelerating privatization and a deeper integration with foreign markets, mainly European. One of the results of the new reforms was the lowering of unemployment rate, which since the days of Bourguiba had presented a serious social problem (King, 2003). Economic analyses published during the years of Ben Ali's rule seemed to confirm the effectiveness of implemented reforms both in terms of macro-economic indicators and social development (Cavatorta, Haugbølle, 2012). The economic achievements of the Ben Ali government, however, look quite different if we take into account the price which had been paid - the price of increased dependence on loans received from international organizations. Between 1987 and 2010, foreign debt increased from 6.8 to 21.7 billion US dollars (International Bank for Reconstruction and Development, 2012; Kempf, 2012).

However, taking into account that for the Bretton Woods institutions the only thing that mattered was that the rates were paid back regularly and the macroeconomic indicators were sound, the government had considerable freedom in disposing of the acquired funds (Hibou, Meddeb, Hamdi, 2011). According to Hibou, loans from international financial organizations were used primarily to strengthen the power of Ben Ali and his family, through economic mechanisms, which had been created for years and facilitated the control and discipline of society. As Tunisia's economic development had become increasingly dependent on external loans, any economic activity within the country that was actually dependent on loans granted by internal financial institutions, was done so on the basis of political and personal as opposed to economic criteria. The growing corruption, and problems of 'bad debts', meant that the survival and functioning of any business became increasingly dependent on the 'good 
will' of the banks, and more specifically - the state (Hibou, 2011). Contrary to conventional wisdom, corruption during Ben Ali's rule was not limited to the circle of people belonging to the so-called 'clans', which comprised of members of the family of the president and his wife, but also significant sections of the society became entangled. Corruption took many different forms, both financial and nonfinancial, ranging from using personal relationships to obtain certain benefits, through to the necessity of giving money for obtaining and securing specific permission, jobs, places in college or bank loans (Hibou, Meddeb, Hamdi, 2011). It is difficult at this point 'to calculate' what was the financial cost of maintaining the whole socio-economic mechanism, but there is no doubt that in this system the middle class was in a more privileged economic position, while the biggest social costs were paid by the lower classes (Ayeb, 2011; Gause, 2011). Of course the problems of unemployment, unequal development of the various regions of the country, and hence unequal access to health services, clean water, and education were also problematic during the Bourguiba rule. However, contrary to the official Ben Ali discourse of the so-called 'economic miracle', liberalization policies did not bring about the reduction of social inequalities and poverty, but rather the opposite.

Undoubtedly one of the reasons why this happened was the aforementioned corruption, which resulted in the misuse of part of the funds that Tunisia received from international financial organizations and from privatization of state enterprises (Kempf, 2012). However, persistent unemployment and poverty were associated largely not only with the rising disparities in development of different regions of the country, where resources from the poorer South were allocated to the development of the more attractive (for tourism) North (Ayeb, 2011), but also with the high level of population growth. Between 1980 and 2010 the Tunisian population increased by four million, from about 6.3 million to 10.4 million. Another problem was that the privatization and restructuring of local enterprises, which could not successfully compete with European companies, resulted in a growing number of redundancies (Zaafrane, Mahjoub, 2000). Moreover, internal and foreign investments focused primarily in the fields where unskilled and cheap labor was required, so the new jobs do not in any way reflect the changes in the structure of Tunisian society, which became increasingly more educated than was the case in the 1980"s (The World Bank, 2014). 


\section{ECONOMIC POLICY IN TUNISIA: CONTINUATION OR CHANGE?}

The removal of Ben Ali from power gave hope to the people that there would be a chance for change, especially in the economic sphere. The authoritarian regime left behind, primarily, a corrupt economic system, high foreign debt, a liberalized economy, a connection with the European Union regarding free trade agreement, huge disparities in development between regions, and a high level of unemployment. The group that was most affected by unemployment were young, educated people. Between 1999 and 2009, unemployment of young graduates increased from $8.6 \%$ to $44.9 \%$. Given that a significant proportion of young people emigrated abroad or found employment in the 'gray zone', the level of unemployment in this period may even have been higher (Paciello, 2011). A similar situation took place in terms of levels of poverty, which jumped after the revolution from the 'official' level of $3.8 \%$ to $11.8 \%$, and in the poorest regions poverty was as high as 30\% (Hibou, Meddeb, Hamdi, 2011).

These problems were further exacerbated after the revolution, because its direct consequence was a slowdown in the economy, rising unemployment, inflation and a crisis in the tourism sector, which constitutes 15\% of GDP. Since the transitional governments did not enjoy popular support, as well as lacking time and resources to initiate any significant changes, in post-revolutionary Tunisia there were expectations that Ennahda, an Islamist party that won the elections to the Constituent Assembly in October 2011, would become the key actor in post-revolutionary economic reforms.

Ennahda, from the beginning of its post-revolutionary activities, presented itself as a party whose goal was to conduct economic policies based on the principles of social justice, and in its first electoral program proposed reforms aimed at reducing the level of unemployment and poverty, development of the poorest regions and bringing economic growth of around 7\% of GDP (Le programme du Mouvement Ennahdha, 2011). From the perspective of less than three years of Ennahda rule, and then the short period of technocratic government headed by Mehdi Jomaa, results in the economic sphere would be far cry from the preelection assumptions. Economic growth, with the exception of 2012, during this period amounted to little more than 2\%; it is also difficult to talk about any success in employment, as unemployment continues to be maintained at the level of $15 \%$ (with the exception of the short post-revolutionary period when unemployment rose to 18\%). If Ennahda has managed to create new jobs it has primarily been in the public sector, which means that the activation policy for 
the private sector in terms of employment did not yield the expected results. Ennahda's policies also brought no tangible results in the development of the poorest regions, where the situation has not changed for decades (Jones, 2013).

The lack of economic improvement is due to several factors. Firstly, Ennahda became drawn into ideological disputes leading to mounting conflict between secular and religious sections of society and conflicts over the constitutional text; as opposed to initiating a serious debate between the various policy centers regarding the model of economic reforms in the country. Secondly, Ennahda wanted to pursue more just social policies, whilst at the same time, accepting a continuation of neoliberal policies, which would include the privatization of state-owned enterprises, a prioritization of foreign investment and increasing flexibility of labor laws (Paciello, 2013). Thirdly, Ennahda politicians themselves repeatedly admitted that the party was unprepared for government, so outside the empty slogans it did not have a clear vision of how to repair the Tunisian economy. However, it is difficult to shoulder Ennahda with the blame for the economic situation in the country. It is necessary to note that after the revolution, Tunisia was in a terrible financial condition. Ben Ali and his family stole 13 billion US dollars' worth of assets, representing more than one-quarter of Tunisian GDP in 2011, and subsequent Tunisian governments have been unsuccessful in recovering this money (Blioua, 2015; Rijkers, Freund, Nucifora, 2014). Moreover, it became problematic for Ennahda that business circles and financial institutions refused to cooperate with its government, which to some extent blocked any change in economic policy (Paciello, 2013). Therefore, the easiest way for Ennahda to bridge the financial gap in the budget became securing more loans granted by international financial organizations, notably the International Monetary Fund and the World Bank. However, Ennahda can be accused of a lack of involvement in efforts towards cancelling the foreign debt left by the previous regime, or at least in its restructuring. Members of the current ruling Nidaa Tounes party also have not protested against further indebtedness. The proposals of the left-wing politicians to demand that international organizations cancel the debts incurred by the Ben Ali regime were rejected, because, as it was argued, the previous regime had used these funds for the development of Tunisia, and therefore, the debt has to be fully repaid (Reidy, 2014).

For its growing debts, however, Tunisia will have to pay a price. Hanieh (2015) analyzed the content of the agreements concluded between Tunisia, the World Bank and the IMF and clearly points out that during the last few years the language used in official statements has become more pro-social but in fact 
both organizations require the same neoliberal reforms from a debtor country as was the case before the Arab Spring. Even if subsequent post-revolutionary governments were so far unable to meet all the requirements set by the Bretton Woods institutions, as those requirements met with considerable opposition from society, the fact remains that these loans are paid in installments in response to the 'progress of reforms', which makes it a convenient tool for exerting pressure on the Tunisian government (Marzouki, Meddeb, 2015). Another problem is that these loans were allocated only to a minimal extent to finance development projects, which would gradually help to pull the economy out of the crisis. Therefore, debt repayment became a serious burden on the budget, which meant that less and less money was spent on public services.

An interesting analysis of the relationship between the level of external debt and economic growth is presented by Mimoun (2013), who based his arguments on research that was conducted, amongst others, by Patillo, Poirson, Ricci and Clemens, Bhattacharya, Nguyen who established the limit for a 'safe' debt at the level of $35-40 \%$ of GDP for developed countries, and 35\% of GDP for low income and developing countries. According to Mimoun, with regards to Tunisia, the safe limit is set at the level of $30 \%$ in relation to GDP. The consequences of going beyond this limit would result in increased spending from the budget for debt repayment, which would in turn translate into reduced GDP growth. As Mimoun calculated for Tunisian external debt, interest rates from 1970 to 2010 grew faster than the debt itself, which means that for every $\$ 100$ borrowed Tunisia would now have to pay back $\$ 195$. According to data from International Monetary Fund (2015) projections, Tunisian external debt at the end of 2015 was to reach a level of 29.8 billion dollars, which accounts for $60.6 \%$ of GDP. The necessity for the repayment of earlier loans means that Tunisian external debt has increased significantly after the revolution, without establishing foundations for future economic growth, which is necessary for the creation of new jobs and economic recovery.

Another aspect, according to Mimoun (2013), that should be taken into account in assessing the real impact of external debt on growth is corruption, because the higher the corruption index, the greater the risk that some of the funds coming from external lenders would be embezzled. This assumption was confirmed in the World Bank report Unfinished Revolution (2014), in which the financial costs associated with corruption were estimated at the level of $2 \%$ of Tunisian GDP, which shows that the problem of corruption has not been solved by the ouster of Ben Ali from power. From such a corrupt system benefited not 
only private companies that were controlled by persons directly linked with power, but also large areas of the public and private sectors can be regarded as involved in corruption, which has changed little even since the revolution. In a survey conducted by Transparency International for a Global Corruption Barometer between September 2012 and March 2013, which takes into account public perceptions of corruption, over $80 \%$ of respondents said that corruption is a problem in the public sector, and $67 \%$ perceive anti-corruption measures taken by the government as insufficient. For the majority of respondents, the most corrupted sectors include the judicial system, the police, the media and various political parties. Most respondents also admitted that they gave bribes to tax office employees (Tunisia 2013 - World's largest opinion survey on corruption - Transparency International). According to the aforementioned report, the numerous regulatory barriers and restrictions in the private sector create ideal conditions for corruption, because a bribe becomes the most common way to bypass existing procedures or to facilitate and speed up formalities. More than a quarter of companies admitted to passing bribes to employees of public administration, and according to estimates, approximately $13 \%$ of corporate income is spent on bribes. An even more common form of corruption is the use of mediation of friends or family members to obtain certain benefits (Nucifora, Churchill, 2014). A similar situation exists in the public sector, which is dominated by people from the former regime, who try to undermine any attempts of change. In an interview with the Tunisian daily La Presse, Samir Annabi, chairman of INLCC (l'Instance nationale de lutte contre la corruption) presented a list of problems that INLCC had to face since its establishment in November 2011. These included the lack of a separate budget, hostility from the part of the judicial system and the administration, and rivalry over funds and responsibilities between INLCC and the Secretary of State for Corruption, appointed by the "Trojka", Ennahda coalition government (Boughdiri, 2014). Nidaa Tounes in turn proposed the controversial Economic Reconciliation Law, which according to critics will weaken the Truth and Dignity Commission, established after the revolution, and will grant amnesty for people responsible for corruption during the Ben Ali regime. This proposal put in question the commitment of the governing Nidaa Tounes towards fighting against corruption (Dahmani, 2015). 


\section{ECONOMIC POLICY, RULE OF LAW AND THE PROCESS OF CONSOLIDATION OF DEMOCRACY}

The question still needs to be asked however, to what extent can the aforementioned analyzed problems affect the processes of democratic consolidation in Tunisia? And what can Tunisia learn, if anything, from the Spanish experience?

First of all, it is necessary to state that all analogies in social sciences carry the risk of oversimplification, misinterpretation and other fallacies, especially when we try to compare cases with different historical and cultural backgrounds, from different times and places. Trying to find similarities between Tunisian and Spanish experiences of political transition, we have to keep in mind that both countries had different levels of economic development before the start of the transition process, different types of political cleavages, and since the beginning of the democratizing processes, both countries had adopted different approaches to the issues of transitional justice and so on. Being aware of all these problems, however, it is still possible to identify certain political strategies that could help us to understand why the Spanish political transition was successful and why it has become so problematic in Tunisia.

As mentioned in the initial part of the article, according to Linz and Stepan, Spain's economic problems have not hampered the consolidation processes, as citizens continued to remember the crimes of the authoritarian regime and the only alternative for them was the democratic system that guarantees respect for human rights and the rule of law. A somewhat different argument was put forward by Bresser-Pereira, Maraval and Przeworski (1994). They consider that the most important reason why the economic crisis did not negatively affect consolidation processes in Spain, was the adoption of more just social policies by the respective governments. Although unemployment in Spain rose from $4 \%$ in the early $70^{\text {s }}$ to $16 \%$ after the transition began, and then to $22 \%$ in 1985 , it did not result in a reduction of support for the ruling party mainly because it promoted pro-welfare policies by increasing expenditure from the budget for social purposes in order to minimize the social consequences of unemployment. However, the policy of the Spanish government was not solely limited to social benefits, but was also aimed at stimulating employment and securing free access to health care and education. As Bresser-Pereira et al. described, the policy of Spain, which focused on social citizenship, accelerated the consolidation processes, because the public "learned that democracy brings also different social rights" (1994, p. 193). 
Tunisia, like Spain during democratic transition, is struggling with the problem of unemployment, which in 2015 held firm at 15,3\% (Statistical Data Bank - Key Indicators, 2015). The difference is, however, that in contrast to Spain, the problem of unemployment did not appear suddenly after major political changes in Tunisia, but had existed long before the removal of Ben Ali from power. Demands raised by protesters at the end of December 2010 had a strong economic and social component. External debt is another important issue that differentiates Spain from Tunisia. While it was not a problem for Spain during democratic transition (Bresser-Pereira et al., 1994), it is a significant burden for Tunisia. Tunisian economic problems should therefore be regarded not as temporary, but as a symptom of a more serious disease resulting from the adoption of a specific model of economic policy during the period of authoritarian rule which can determine to a large extent the future of this young democracy. Moreover, the promises given by democratically elected politicians that have not materialized, only serve to reduce the trust of citizens, especially the young people in democratically elected authorities, as it is increasingly difficult for them to differentiate between the period 'before' and 'after' the revolution.

The previous undemocratic and corrupt government was seen as incapable of addressing social and economic problems, which led to protests and resulted in regime change. Obviously, one cannot forget that this revolution was not just about the economy. It was also about freedom, which in almost all respects was restricted by the authoritarian government. However, this does not change the fact that economic issues continue to occupy a prominent place on the list of social priorities. For example, in a study conducted in October 2014 by Pew Research, 96\% percent of the respondents believed that an improvement of the economic situation is the most important issue for the Tunisian future (Tunisian Confidence in Democracy Wanes, 2014). Hence, democratically elected authorities will be judged through the prism of effectiveness of their governments in solving the most important economic and social problems, which are connected to another one - exclusion, both political and economic.

Exclusion primarily affects young Tunisians and its source is not only poverty but also a high level of unemployment. The largest percentage of unemployment is among young people - in some areas of the country up to $85 \%$ of young people remain without a job (Investing in Youth, 2015). Successive governments hoped that the implementation of numerous governmental programs would reduce levels of unemployment. However, as shown in the report prepared by the Tunisian researchers under the auspices of the European Training Foundation, the 
results of these programs are far from expected, as the decisions of the companies regarding hiring new employees had nothing to do with candidates' participation in governmental programs (Zouari, 2014). The ineffectiveness of these programs also stems from the fact that in a large part they are aimed at stimulating employment in areas where there is already considerable market saturation (Investing in Youth, 2015). Despite its ineffectiveness, the same strategy was adopted by Nidaa Tounes, which won the parliamentary elections in October 2014. One of the most important elements of its electoral program was to reduce as soon as possible the level of unemployment. They proposed to establish the "Young Corps" serving as a platform for education and training for the young unemployed, cooperating with local schools, and community centers. According to the electoral program, the activities of the "Young Corps" should result in thousands of new jobs in 2015 and 2016. Nidaa Tounes also planned to launch new programs for the unemployed and promote employment in the framework of family business projects (Notre programme pour un développement ambitieux au service de tous les Tunisiens, 2014). However, more than one year after the appointment of the new government, none of the planned programs had been implemented.

The lack of vision for lowering the level of unemployment, however, is a reflection of a broader problem. After the revolution, successive governments have failed to invest greater efforts into preparations with different social groups for comprehensive plans of economic reform, allowing for a break with the economic policies of the previous regime. This discrepancy between election promises and the subsequent activities of the ruling parties has meant that the gap between the older and younger generations appears to be growing. As Marks (2013) noted, in post-revolutionary Tunisia generational divisions are increasing, because young people have limited opportunities to fulfil life stability and they do not view the politicians as their representatives, in that they are perceived as belonging mainly to the old generation and in fact represent the prosperous middle-class. The elite political class is seen by most of Tunisian society as corrupt and concerned only with realizing their narrow interests rather than the interests of the general public. The most disappointed sections of society are the young people who took part in the protests, and in a regime change they perceived as an opportunity to improve the economic and political situation. Meanwhile, a large part of the political classes, consists of people from the old regime, who benefited most from the corrupt system created by Ben Ali and tend to have little interest in change. Regarding the religious middle class represented by Ennahda, even if its ideology highlights the importance of pro-social policy, in 
practice it is primarily guided by the logic of the market, which makes Ennahda not much different from its 'secular' counterpart, Nidaa Tounes.

Therefore, economic problems in Tunisia will have a different meaning if we look at them also from the perspective of class conflicts and the policy of exclusion of different social groups - the issue which was analyzed by Merone (2015). In his article, he proposes that the current ideological and economic conflicts and growing extremism should be analyzed from the perspective of class conflict, the roots of which can be tracked back to the early days of independence and the struggles between different social groups for equal participation in the processes of nation building. The former division between president Habib Bourguiba and Salah Ben Youssef continues to feed the political divisions in the country. But during the rule of Bourguiba and at the beginning of the Ben Ali regime it was the religious middle class belonging to the Salah Ben Youssef faction which had fought for inclusion into the decision-making structures, then in the postrevolutionary period those excluded from the political process are the masses comprising of those excluded both economically and politically. The so-called 'new excluded' live primarily in the poorest regions of the country with the highest levels of unemployment and since the late $1990^{\text {s }}$ their representatives became different Salafi groups, both apolitical and those using violent means. Obviously it should be stressed at this point that the problem with religious radicalism is much broader, and one cannot narrow it down solely to everyday, bread and butter issues. Tunisia, however, is an example of a country where economic issues are closely linked to problems of security and without addressing the former it is not possible to address the issue of terrorist organizations and their activities. Such activities, especially in the poorest regions, are possible because of help from the local population, for which the provision of 'services' to the jihadists is often the only way to make money. Kasserine city, located near Mount Chaambi and close to the border with Algeria, where members of jihadi group Ansar al-Sharia are hiding, is one of many such examples. Local people make a living from smuggling or cooperating with jihadists (Khatib, 2014). This situation applies to border areas with Algeria as well as with Libya, and the cooperation between the jihadists and smugglers is profitable for both, which makes it all the more difficult to combat such armed groups (Boukhars, 2015). Smuggling in turn has reached such epic proportions after the revolution that its value has been estimated as approximately equivalent to around 38\% of GDP, according to 'optimistic' data, or even as much as $53 \%$ of GDP or 40 billion Tunisian dinars per year. The so-called 'informal' employment sector accounts for an estimated 
$54 \%$ of the Tunisian workforce and the prospects of work are unpredictable, often seasonal and without any legal protection (Léconomie informelle en Tunisie, 2015). Many young people in the poorest regions therefore often find themselves on the horns of a dilemma - contemplating involvement in trafficking or in the activities of jihadists operating locally. According to estimates, Tunisia is the country that has provided the highest number of people to join the Islamic State (approx. 3,000). Sayida Ounissi, a parliamentarian from Ennahda, commented on this phenomenon as follows: "It happens when you are not giving perspectives to young people inside the country. What does it mean to go to Daesh, is it not a form of suicide, a form of leaving everything behind you, when you have nothing else to lose? We have to also look at this problem from a very social perspective, not only religious, because it doesn't explain everything...”3.

But as Linz and Stepan mentioned above, support for democracy is not only about the economy but it is also about the rule of law and respect for human rights. In Tunisia, in contrast to the experiences of Spain, in the area of human rights, things have not changed that much, despite the adoption of many new regulations. The use of torture against detainees is still prevalent in detention centers and prisons, and the police act with impunity with officers violating their powers and as such are rarely accountable for their actions (Strickland, 2014); basically the justice system is corrupt and still functions as it did during the Ben Ali rule (Achouri, 2013; Mersch, 2015). Because of this, for the average citizen the concepts of 'human rights' and 'rule of law' do not constitute arguments in favor of democracy. Another issue is the activities of terrorist groups, whose attacks only encourage an expansion of the powers of the security apparatus at the expense of respect for human rights, as has happened with the new counterterrorism laws (Amnesty International, 2015, 2016; Human Rights Watch, 2015). The consequence of this state of affairs, however, is growing frustration and a shrinking belief in citizens that the democratic system is advantageous compared to other regime types. In the previously cited study of public opinion conducted by Pew Research in October 2014, less than four years after the start of the protests, only $48 \%$ of respondents recognized democracy as a preferred system of government (in 2012, this response was provided by $63 \%$ of respondents), and $24 \%$ answered that the form of government does not really matter (in comparison to 2012 when this response accounted for $11 \%$ of respondents).

${ }^{3}$ Unpublished interview held by Konrad Pędziwiatr with Sayida Ounissi in Tunis, December 2014. 
What is more, $26 \%$ said that sometimes non-democratic form of power may be more favorable (Tunisian Confidence in Democracy Wanes, 2014). For comparison, in Spain during its transition period, support for democracy remained at the level of $69-81 \%$, and the number of opponents of democracy never exceeded 20\% (Linz, Stepan, 1996, p. 108).

\section{CONCLUSIONS}

Tunisia's experience of more than five years of political transformation confirms the assumptions of researchers treating economic factors as crucial to the processes of democratization. According to Przeworski, Alvarez, Cheibub, Limongi (1996), economic factors not only have a significant impact on the survival of democracy; they also tried to calculate for how long young democracies can survive in conditions of economic crisis. As they point out, the level of development and accumulated wealth is not the most important factor. Much more important is what kind of policies the state is conducting in order to stimulate economic growth and reduce social inequalities, and in this way contribute to improvements in the standard of living for society as a whole, and not just a small part of it. Otherwise, democracy has little chance not only to successfully complete processes of consolidation, but also to survive. Przeworski and Fernardo Limongi (Linz, Stepan, 1996, p. 72), on the basis of the experiences of South American states during the years 1944-1988, have come to the conclusion that the probability of survival for a democratic regime having endured five consecutive years of negative growth is only $50 \%$, and for each subsequent year this probability is decreasing.

Tunisia is an example of a country where economic policy does not contribute to minimizing socio-economic exclusion, because in the period after the Arab Spring successive governments were unable to break free from the economic development model which had been promoted by the authoritarian state. This economic model, based on economic liberalization, privatization, an unequal development of different regions of the country and growing external debt, contributed to an emergence of extreme differences in the development of various regions of the country, and hence to the co-existence of areas of prosperity and relative wealth on the one hand, and high unemployment and poverty on the other. This is a key issue, since the extent to which different groups of citizens 
will be included in economic and consequent political processes depends on the economic policies of the state, which in turn have a great impact on the stability of the young democracy.

\section{REFERENCES:}

Acemoglu, D., \& Robinson, J.A. (2006). Economic Origins of Dictatorship and Democracy. New York: Cambridge University Press.

Achouri, M. (2013). Tunisian Judicial System In Need of Serious Reform. Retrieved from http://www.al-monitor.com/pulse/politics/2013/09/tunisia-judicial-judges-reform. html.

Amnesty International (2015). Tunisia: Sweeping Crackdown Signals Abuse of Emergency Measures. Retrieved from: https://www.amnesty.org/en/latest/news/2015/12/ tunisia-sweeping-crackdown-signals-abuse-of-emergency-measures/.

Amnesty International (2016). Tunisia: Evidence of Torture and Deaths in Custody Suggest Gains of the Uprising Sliding into Reverse Gear. Retrieved from: https:// www.amnesty.org/en/latest/news/2016/01/tunisia-evidence-of-torture-and-deathsin-custody/.

Ayeb, H. (2011). Social and Political Geography of the Tunisian Revolution: The Alfa Grass Revolution. Review of African Political Economy, 38 (129), 467-479. DOI: 10.1080/03056244.2011.604250.

Blioua, I. (2015). I Watch: Fate of the Stolen Money. Retrieved from: http://www.tunisialive.net/2015/02/02/i-watch-fate-of-the-stolen-money/.

Boix, C. (2003). Democracy and Redistribution. Cambridge, UK, New York: Cambridge University Press.

Boughdiri, I. (2014). La lutte contre la corruption est un processus très long qui a besoin de militantisme. Retrieved from: http://fr.allafrica.com/stories/201412101524.html.

Boukhars, A. (2015). The Reckoning: Tunisia's Perilous Path to Democratic Stability. Retrieved from: http://carnegieendowment.org/2015/04/02/reckoning-tunisia-sperilous-path-to-democratic-stability/i5cj.

Bresser-Pereira, L.C., Maravall, J.M., \& Przeworski, A. (1994). Economic Reforms in New Democracies: A Social-Democratic Approach. In: W.C. Smith, C.H. Acuña, \& E. Gamarra (eds.), Theoretical and Comparative Perspectives for the 1990s (p. 181-212). New Brunswick, USA: Transaction Books.

Carothers, T. (2002). The End of the Transition Paradigm. Journal of Democracy, 13 (1), 5-21.

Cavatorta, F., \& Haugbølle, R.H. (2012). The End of Authoritarian Rule and the Mythology of Tunisia under Ben Ali. Mediterranean Politics, 17 (2), 179-195. DOI: 10.1080/13629395.2012.694043.

Dahmani, F. (2015). La réconciliation tunisienne en suspens. Retrieved from: http:// www.jeuneafrique.com/231027/politique/la-r-conciliation-tunisienne-en-suspens/, accessed 20.06.2015. 
Gause, G.F. (2011). Why Middle East Studies Missed the Arab Spring: The Myth of Authoritarian Stability. Foreign Affairs, 90 (4), 81-90.

Haggard, S., \& Kaufman, R.R. (1997). The Political Economy of Democratic Transitions. Comparative Politics, 29 (3), 263-283. DOI: 10.2307/422121.

Haggard, S., \& Kaufman, R.R. (2012). Inequality and Regime Change: Democratic Transitions and the Stability of Democratic Rule. American Political Science Review, 106 (3), 495-516. DOI: 10.1017/S0003055412000287.

Hanieh, A. (2015). Shifting Priorities or Business as Usual? Continuity and Change in the post-2011 IMF and World Bank Engagement with Tunisia, Morocco and Egypt. British Journal of Middle Eastern Studies, 42 (1), 119-134. DOI: 10.1080/13530194.2015.973199.

Hibou, B. (2011). The Force of Obedience: The Political Economy of Repression in Tunisia. (trans. A. Brown). Cambridge: Polity Press.

Hibou, B., Meddeb, H., \& Hamdi, M. (2011). Tunisia After 14 January and Its Social and Political Economy: The Issues at Stake in a Reconfiguration of European Policy. Copenhagen: Euro-Mediterranean Human Rights Network.

Houle, C. (2009). Inequality and Democracy: Why Inequality Harms Consolidation but Does Not Affect Democratization. World Politics, 61 (4), 589-622. DOI: 10.1017/ S0043887109990074.

Human Rights Watch (2015). Tunisia: Counterterror Law Endangers Rights. Retrieved from: https://www.hrw.org/news/2015/07/31/tunisia-counterterror-law-endangersrights.

Huntington, S.P. (1991). The Third Wave: Democratization in the Late $20^{\text {th }}$ Century. Norman: University of Oklahoma Press.

International Bank for Reconstruction and Development (Ed.). (2012). External Debt of Developing Countries. Washington, DC: World Bank.

International Monetary Fund (2015). 2015 Article IV Consultation, Sixth Review Under the Stand-By Arrangement, and Request for rephasing - Press Release; Staff Report; and Statement by the Executive Director for Tunisia (IMF Country Report No. 15/285). Retrieved from: https://www.imf.org/external/pubs/ft/scr/2015/cr15285. pdf.

Investing in Youth: Tunisia. (2015). OECD Publishing. Retrieved from: http:// www.oecd-ilibrary.org/social-issues-migration-health/investing-in-youthtunisia_9789264226470-en. DOI: 10.1787/9789264226470-en.

Jones, S. (2013). Three Years After Tunisian Street Vendor Ignited Arab Spring, His City Still Suffers. Retrieved from: http://www.huffingtonpost.com/2013/12/18/tunisiarevolution-arab-spring_n_4462064.html.

Kempf, R. (2012). Should Tunisia Pay Ben Ali's Debts? Retrieved from: http://www. jadaliyya.com/pages/index/5502/should-tunisia-pay-ben-alis-debts.

Khatib, L. (2014). Tunisia's Security Challenge. Retrieved from: http://carnegie-mec. org/2014/11/26/tunisia-s-upcoming-challenges/hvfs.

King, S.J. (2003). Liberalization against Democracy: The Local Politics of Economic Reform in Tunisia. Bloomington, Ind: Indiana University Press. 
Le programme du Mouvement Ennahdha (2011).

Léconomie informelle en Tunisie: Etat des lieux et solutions possibles. (2015). Retrieved from: http://www.kapitalis.com/kapital/28634-l-economie-informelle-en-tunisieetat-des-lieux-et-solutions-possibles.html.

Linz, J.J., \& Stepan, A. (1996). Problems of Democratic Transition and Consolidation: Southern Europe, South America, and Post-Communist Europe. Baltimore: Johns Hopkins University Press.

Marks, M. (2013). Youth Politics and Tunisian Salafism: Understanding the Jihadi Current. Mediterranean Politics, 18 (1), 104-111. DOI: 10.1080/13629395.2013.764657.

Marzouki, N., \& Meddeb, H. (2015). Tunisia: Democratic Miracle or Mirage? Retrieved from: http://www.jadaliyya.com/pages/index/21863/tunisia_democratic-miracleor-mirage.

Merone, F. (2015). Enduring Class Struggle in Tunisia: The Fight for Identity beyond Political Islam. British Journal of Middle Eastern Studies, 42 (1), 74-87. DOI: 10.1080/13530194.2015.973188.

Mersch, S. (2015). Judicial Reforms in Tunisia. Retrieved from: http://carnegieendowment.org/sada/ ?fa $=59746$.

Mimoun, B.M. (2013). Assessing the Short- and Long-run Real Effects of Public External Debt: The Case of Tunisia. African Development Review, 25 (4), 587-606. DOI: 10.1111/1467-8268.12054

Murphy, E. (1999). Economic and Political Change in Tunisia: From Bourguiba to Ben Ali. New York: St. Martin's Press in association with University of Durham.

Notre programme pour un développement ambitieux au service de tous les Tunisiens. (n.d.). Nidaa Tounes, Commission économique et sociale. Retrieved from: http:// directinfo.webmanagercenter.com/docs/Programme-NIDAA-TOUNES-FR.pdf.

Nucifora, A., Churchill, E. (2014). Tunisia’s Economic Status Quo. The Washington Post. Retrieved from: http://www.washingtonpost.com/blogs/monkey-cage/ wp/2014/10/22/tunisias-economic-status-quo/.

Paciello, M.C. (2011). Tunisia Changes and Challenges of Political Transition. Brussels: Centre for European Policy Studies. Retrieved from: http://www.ceps.eu/book/ tunisia-changes-and-challenges-political-transition.

Paciello, M.C. (2013). Delivering the Revolution? Post-uprising Socio-economics in Tunisia and Egypt. The International Spectator, 48 (4), 7-29. DOI: 10.1080/03932729.2013.847674

Przeworski, A. (1991). Democracy and the Market: Political and Economic Reforms in Eastern Europe and Latin America. Cambridge, New York: Cambridge University Press.

Przeworski, A., Alvarez, M.E., Cheibub, J.A., Limongi, F. (2000). Democracy and Development: Political Institutions and Well-Being in the World, 1950-1990 (1 ${ }^{\text {st }}$ edition). Cambridge: Cambridge University Press.

Reidy, E. (2014). Nidaa Tunis, Ennahda Agree on Economic Policy. Retrieved from: http://www.al-monitor.com/pulse/originals/2014/12/tunisia-nidaa-tunis-ennahdaeconomy-imf-world-bank.html. 
Rijkers, B., Freund, C.L., Nucifora, A. (2014). All in the Family: State Capture in Tunisia (SSRN Scholarly Paper No. ID 2415016). Rochester, NY: Social Science Research Network. Retrieved from: http://papers.ssrn.com/abstract=2415016.

Rothstein, B. (2014). Quality of Government and Democratic Consolidation. Comparative Democratization - The American Political Science Association, 12 (2), 1, 3-6.

Statistical Data Bank - Key Indicators. (2015). Retrieved from: http://www.ins.nat.tn/ indexen.php.

Stepan, A.C., Linz, J.J. (2001). Political Crafting of Democratic Consolidation or Destruction: European and South American Comparisons. In: A.C. Stepan, Arguing Comparative Politics (p. 138-158). Oxford: Oxford University Press.

Strickland, P.O. (2014). Police Brutality Barely Mentioned at Tunisia's Elections Campaigns. Retrieved from: http://www.middleeasteye.net/in-depth/features/policebrutality-barely-mentioned-tunisia-s-elections-campaigns-1302679400.

The World Bank (2014). The Unfinished Revolution. Bringing Opportunity, Good Jobs and Greater Wealth to All Tunisians (Development Policy Review Report No. 86179-TN).

Tunisia 2013 - World's Largest Opinion Survey on Corruption - Transparency International. Retrieved from: http://www.transparency.org/gcb2013/ country? country=tunisia.

Tunisian Confidence in Democracy Wanes (2014). Pew Research Center, 15 October 2014. Retrieved from: http://www.pewglobal.org/2014/10/15/tunisian-confidencein-democracy-wanes/.

Zaafrane, H., Mahjoub, A. (2000). The Euro-Mediterranean Free Trade Zone: Economic Challenges and Social Impacts on the Countries of the South and East Mediterranean. Mediterranean Politics, 5 (1), 9-32. DOI: 10.1080/13629390008414706.

Zouari, S. (2014). Employment Policies and Active Labour Market Programmes in Tunisia. European Training Foundation. Retrieved from: http://www.etf.europa. eu/webatt.nsf/0/B32C0FCEDB47113DC1257D0100405D0F/\$file/Employment\%20 policies_Tunisia.pdf. 